\title{
Medical Publishing in Portugal in the First Half of the Seventeenth Century: A Good Business?
}

The title of this chapter prompts a series of questions. Was there a distinctive medical book market, and if so what did it look like within the broader world of the book? Was it Portuguese, or might we better think in Iberian or even European terms? Was medical publishing a profitable activity? Let us attempt to address these issues, and explore the connections between producers and consumers (buyers, readers, censors) and how these relationships evolved over the course of the first half of the seventeenth century.

\section{The Portuguese Medical Book Market (1600-1650): A Question of Statistics}

There was a very significant increase in overall book production over the course of the sixteenth and seventeenth centuries. 1 A simple glance at the figures for Portugal (Fig. 1) indicates a rise in production from 1,537 items between 1500 and 1599 to 3,818 for the first half of the seventeenth century. 2

Nonetheless, there was no continuous or lineal evolution of the market. After an initial and clear increase, there was near stagnation. The highest and lowest levels of production can be observed within a very short period: 1638 saw the publication of 35 items, while 248 items were published just three years later (Fig. 2 and Fig. 3).

Number of items

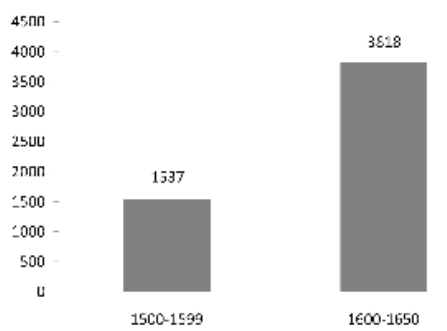

Figure 1. 


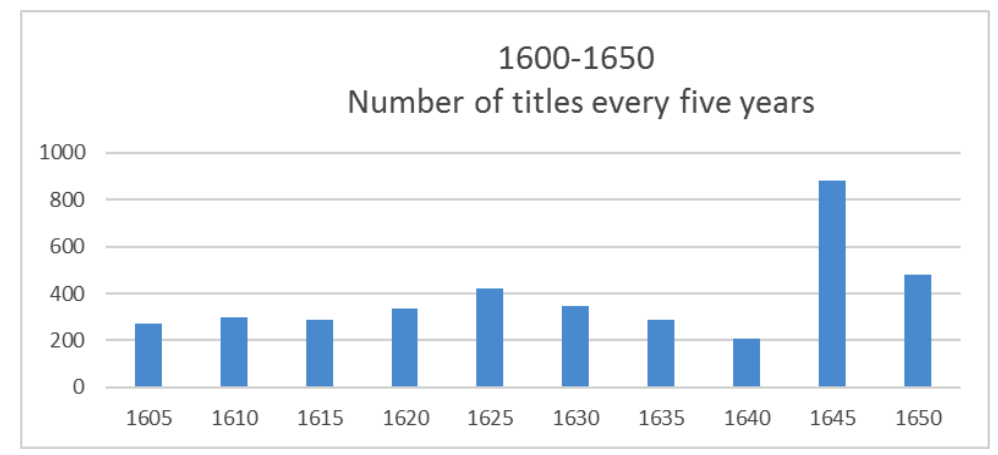

Figure 2.

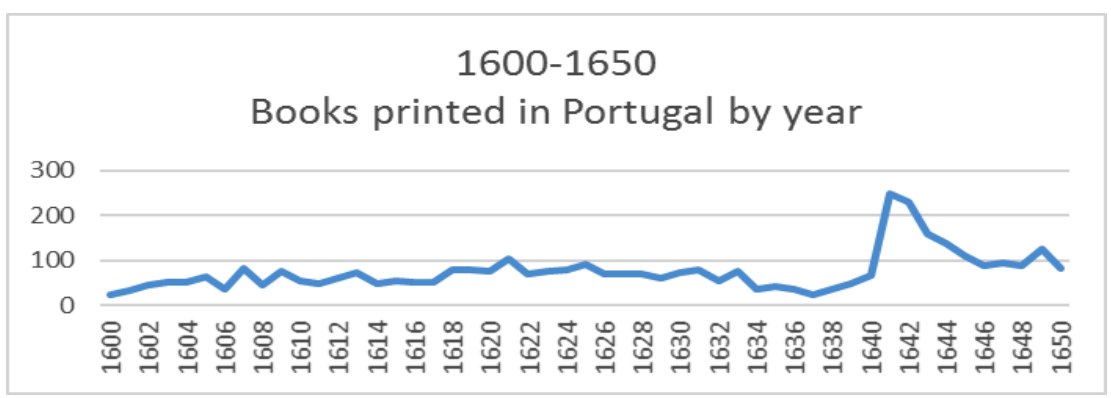

Figure 3.

In terms of the medical book market, 39 works were published by twentytwo authors in the first half of the seventeenth century, or an average of one item every two years. 3 The peak occured during the 1640s. In general terms, however, medical books remained a very small part of the overall market, equivalent to around 1.1 per cent of total output.

We can also adjust these figures for population size:

Portugal: 101 items were printed for the seventeenth century as a whole out of a population of 1.5 million $=$ circa $0.6 / 10.000$ inhabitants. Spain: 728 items were printed out of a population of 6.6 million $=$ circa $1 / 10.000$ inhabitants. 4

Britain and associated territories: 400 items were printed out of a population of 5.6 million $=$ circa $0.8 / 10.000$ inhabitants. 5

Over the course of the seventeenth century, Portugal produced fewer medical books per capita than either Spain or the British Isles.6 Of course, what was printed in a given region can only tell us so much about levels of consumption. While there was no Portuguese production whatsoever of anatomical works in the seventeenth century, this does not mean that there was no interest in the subjet. There appears to have been a vibrant trade in imported books, including classical texts in Latin such as Galen, as well as more contemporary writers such as Mondini de Luzzi, Andreas Vesalius, Charles Estienne, Felix Platter, Guido Guidi, Jean Bauhin, and André Du Laurens.7 More rarely, vernacular translations, principally in Spanish and Italian, also circulated - not least Vesalius' partly plagiarized Anatomia of Juan Valverde.8 One of the reasons Portuguese printers were so reluctant to engage directly in producing such works was the heavy investment required to produce illustratations. Illustrated Portuguese medical works are 
incredibly rare. One example is contained in the treatise of Antonio da Cruz, where we can find an image of a zodiac-man (Fig. 4).9 Perhaps tellingly, this illustration was not reproduced in subsequent editions, but a copy does appear in the Thesouro de prudentes by Gaspar Cardoso Sequeira.10 It is not of anatomical use. The only other illustration of which I am aware is an un-Vesalian image of a man showing the vena cava and the liver which appears in the Correç̧ão de abusos published by Manuel de Azevedo in 1668.11

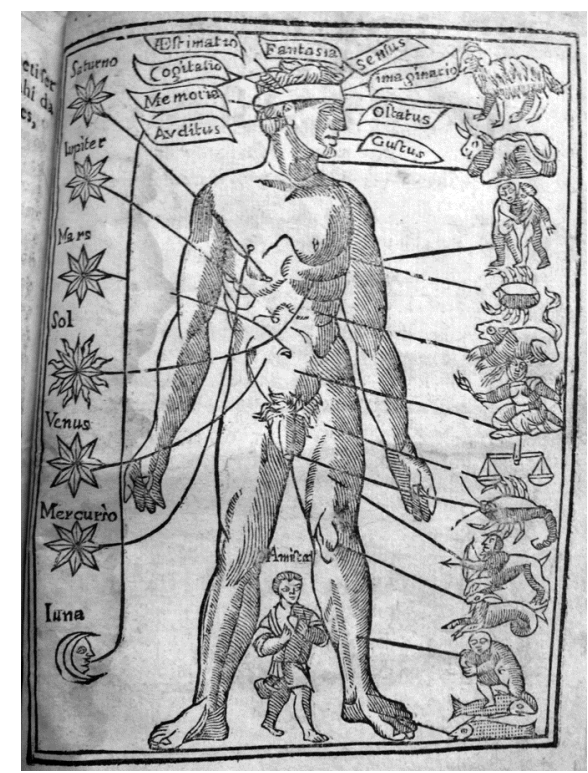

Figure 4. Zodiac man.

\section{Patterns of publication}

Overall, however, there appears to have been very little enthusiasm amongst Portuguese publishers and printers for producing medical texts. For the seventeenth century as a whole, we know of 76 Portuguese authors active in writing medical literature. 28 of these authors remained unpublished.12 While there were 101 medical works printed in this century, we know of at least 78 unpublished manuscripts. 13

In terms of what was produced during the seventeenth century, Lisbon was the largest printing centre in Portugal, and more than 70 per cent of medical texts published in the country emerged from its presses. A further 22 per cent of medical items ( 8 items) were published in Coimbra. Other minor centres were also acrtive during the first half of the century: Évora, Braga and Vila Viçosa. Ostensibly, we might have expected a slightly higher figure for Coimbra, given that the country's only Faculty of Medicine had been located there since 1536. This was not the case. A similar situation existed in Salamanca which published only 9 out of 728 medical editions printed in Spain. Printers in Coimbra and Salamanca appear not to have been overly interested in their repsective local academic markets. These were catered for largely through student handbooks circulated in manuscript form ( livros de letra de mão »), made by copiers - a practice that continued well into the twentieth century called sebentas.

An examination of the typology of Portuguese medical texts is also revealing. Theoretical works on areas such as medical philosophy, or commentaries of classical 
texts accounted for 23 per cent of the output, while practical texts on subjects such as surgery and diet constituted 77 per cent. Of the 39 items, 24 were originals $(61,5$ per cent) and 15 were reprints (38,5 per cent) (Fig. 5). In two decades, from 1610 to 1630, we can see that 7 original texts appeared, whereas there were 8 editions of republished work. Interestingly, there were no reprints of theoretical works - only works of practical medicine merited subsequent editions. Over the course of the first half of the seventeenth century, the names of two authors were pre-eminent: António da Cruz and Gonçalo Cabreira with four reprints each.14 Both were compilers, with the former reworking Guy de Chauliac (1298?-1368), while the latter was responsible for deftly weaving together extracts from the thirteenth-century Thesaurus Pauperum.15

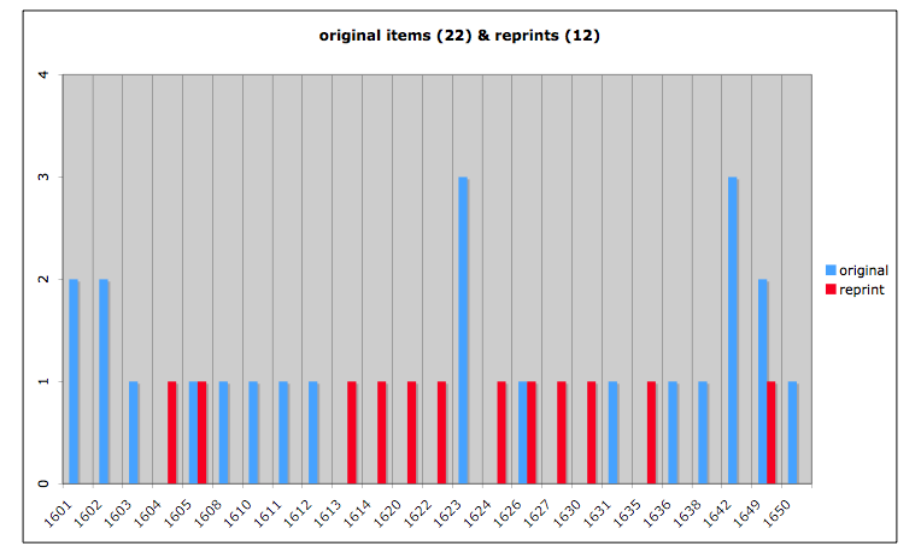

Figure 5 Original items and reprints.

An examination of the language of the works is also revealing. If we look at all items, that is original works and reprints, 30,8 per cent were in Latin, 20,5 per cent in Spanish and 48,7 per cent in Portuguese.16 If we focus only on the original works (27), 33,3 per cent were in Portuguese, 50 per cent in Latin and 16,7 per cent in Spanish. These figures tend to refute the general decline in Latin publication, a trend witnessed across Europe. But if we look beyond the number of items and look also at their size, Portuguese publishing overcomes the Latin one -565 sheets (44,5 per cent of the total) were printed in Portuguese, and 443 sheets in Latin (35 per cent). The Spanish sheet count, in contrast, was around 225, that is a fifth of the total.17 Latin remained the language used for theoretical medicine texts, including the only in-folio printed in Portugal at the time.18 Manuscript medical culture was somewhat different, with, for the period from 1601 to 1700, some 65,8 per cent of known items in Latin, 30,4 per cent in Portuguese and 1 per cent in Spanish.19

The number of Spanish medical texts was not simply a consequence of the political situation of Portugal, dominated since 1580 by the Spanish Crown. It was also the result of strong cultural influence. Within the medical world itself, there were established connections between Coimbra and Salamanca, as well as the presence of Spanish physicians at the Portuguese Court.20 Two Spanish medical authors were only ever printed in Portugal - António Viana and António de Castro.21 It is unlikely that their 
works were printed in Portugual solely for export. 9 copies of Castro's book can be found in Portuguese libraries, one in Madrid and London. In 1621, João da Costa, a surgeon of Lamego, far from any major urban centre, owned 13 books, 6 of which were medical texts.22 5 of those were in Spanish, including Ambrosio Nunes's treatise of 1601.

In short, the Portuguese medical book market was dominated largely by vernacular and practical medical texts, some of which were reprinted many times. As to the circulation of books, the question of print run is always difficult to answer.23 The statistics of existing copies might, however, offer us some indication of likely circulation patterns. 5 of the 39 editions ( 13 per cent) have no known surviving copy.24 For the rest, 301 copies are known in 65 libraries (22 in Portugal) - 172 copies in Portugal, 48 in Spain and 40 elsewhere. Almost all editions have at least one copy in a Portuguese library.25 It would appear then that most books printed in Portugal were destined for the domestic market.26 Before 1650, Lisbon was already the dominant centre of Portuguese printing, responsible for at least three quarters of all production.27 The capital was not, however, well connected to international markets and to the wider academic public. 28 That is not to say, however, that Portuguese scholarship did not have some international reach. Take, for instance, Duarte Madeira Arrais. A chapter of his Latin work printed in 1650 and entitled De arboris vitae paradisi qualitatibus, was translated into English and included in Roger Bacon's The Cure of Old Age in 1683.29 Two other Portuguse authors were also well disseminated - Ambrosio Nunes and Fernão Cardoso.30 Both authors were late representatives of medical humanism, and wrote in Latin.

Who were the buyers and the readers of medical books? Obviously, demand came first from those with a professional interest in this type of literature. We encounted one example earlier - Jerónimo da Costa, the surgeon from Lamego who owned six medical books, from a total of 13, two of which were printed in Portugal, while the other four were printed in Spain.31 In addition, institutions also sought out medical literature - not least hospitals, convents, and colleges. One of the most important Portuguese medical libraries was the botica of the monastery of Santa Cruz in Coimbra. The binding of a copy of Cabreira (Fig. 6), made of an antiphonary, may reflect its common use within a religious milieux.32

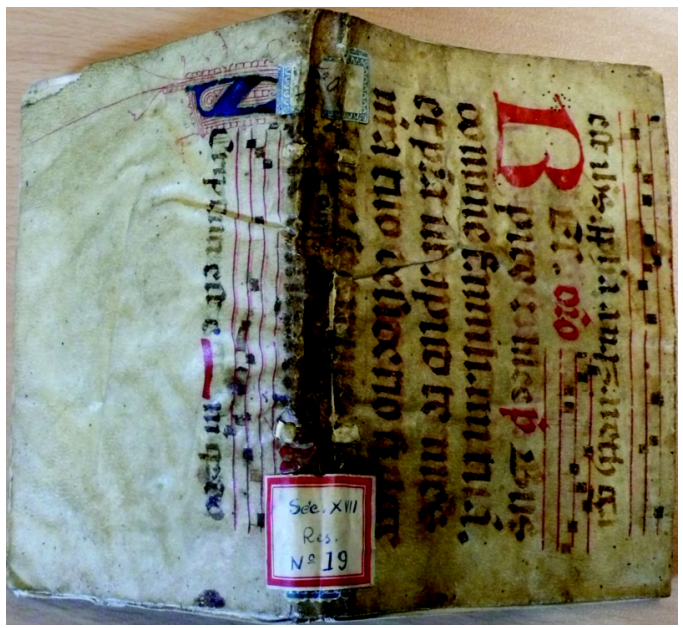

Figure 6 The binding of a copy of Cabreira. 
Hervé Baudry, « The Portuguese Medical Book Market (1601-1650) : a Good Business ? », in A Maturing Book Market? ed. Alexander Wilkinson (Leiden: Brill, Library of the Written Word, 2017, ch. 12, 225-240)

\section{The Portuguese Market within an Iberian Context}

From 1580 until 1640 was the period of the Dual Monarchy. The king of Spain was also ruler of Portugal.33 The statistics in the overall Portuguese book market showed extremes of production in the 1640s, a depression followed by a peak around 1641-1642 - the recovery of independence. Politics may have had some influence in medical publication too. Authorship and individual strategies for publication are determined in part by events, and by physicians looking for protectors and charges in the new state.34

As Ana Paula Megiani has observed, 'few people read, the Inquisition is on watch, but books increase'.35 In the early 1600s, Tridentine procedures for the control of books and ideas, for their prohibition or expurgation, exerted their influence on the book market. Unlike in other parts of Europe, printing never became an instrument of controversial ideas in Portuguese society.36

The Iberian book market as a whole was tightly dependent on the controlling system, from authors to readers. The biggest contribution to Portuguese medicine in the Renaissance came from migrants, mainly Sephardim, who preferred exile to forced conversion or conversos eager to relive the mosaic faith. The 'Lusitani' referred to by some local authors as 'nostri' came back home between the covers of printed books.37 Manuel Brudo, Rodrigo de Castro, Estevão Rodrigues de Castro, Rodrigo da Fonseca, Felipe/Elijah Montalto, and others, belonged to the Portuguese medical diaspora. Amato Lusitano and Zacuto Lusitano, indexed in the expurgatories, circulated under hard control in Portugal.38

In Portugal, authors and readers were constantly confronted with the presence of censorship. Printed books were rewritten and many reedited with a corrected text. Reading books in any field, whether in the sciences, law, theology, or humanities, was an activity that was strictly controlled. The Inquisition aimed to provide a safe reading environment, for a society 'threatened by impurity'.39 Advising the reader, some censors wrote in Latin "tuto lege" (read safely) on the front-page of expurgated books. The impact of their activity should not be underplayed, for it affected intellectual activity radically. If not 100 per cent of books, then certainly the majority, were controlled and individual expression was strongly determined from above. The reader was constantly reminded of the danger through marks made within the books themselves. Dissuasive and intimidating means were a permanent dimension of inquisitorial censorship in earlymodern culture. Marquilhas has argued that the Inquisition adopted a weak policy on scientific publishing in Portugal.40 Given the overwhelming evidence of expurgation, this argument simply cannot hold. Focused on the indivudal as reader, it was highly effective in Portugal.41

In what ways could the inquisitorial practices have affected the local market? In terms of medical books printed in Portugal in the first half of the seventeenth century, three titles by three authors were censored. Two of these authors were Portuguese, Gonçalo Cabreira and Gaspar Cardoso de Sequeira, while the other, Oliva Sabuco, was Spanish.42 As none of these authors was deemed heretical, they did enter the second class of the Lisbon Index in 1624.43 They could also be found in the Spanish Indices of 1632 (Seville) and 1640 (Madrid).44 In Fig. 7, we can see parts of the copies of Sequeira which have been erased.45 Sabuco's re-edition published in Braga (1622) was the expurgated version of the previous editions printed in Spain in 1587 and 1588.46 The 
Hervé Baudry, « The Portuguese Medical Book Market (1601-1650) : a Good Business ? », in A Maturing Book Market? ed. Alexander Wilkinson (Leiden: Brill, Library of the Written Word, 2017, ch. 12, 225-240)

case of Cabreira's treatise is more complex due to the expurgating process which likely begun at the time of the fourth impression of 1617, then dated 1624.47 Except for these three censored books, only two other medical works were not printed within the year of the first license. As shown in Fig. 8, with a total of 25 items (showing licensing data), 8 exceeded one year, that is 32 per cent, of which two were subjected to expurgation (Sabuco and Cabreira). Perhaps other factors, still to be studied, would help clarifying the disparities.

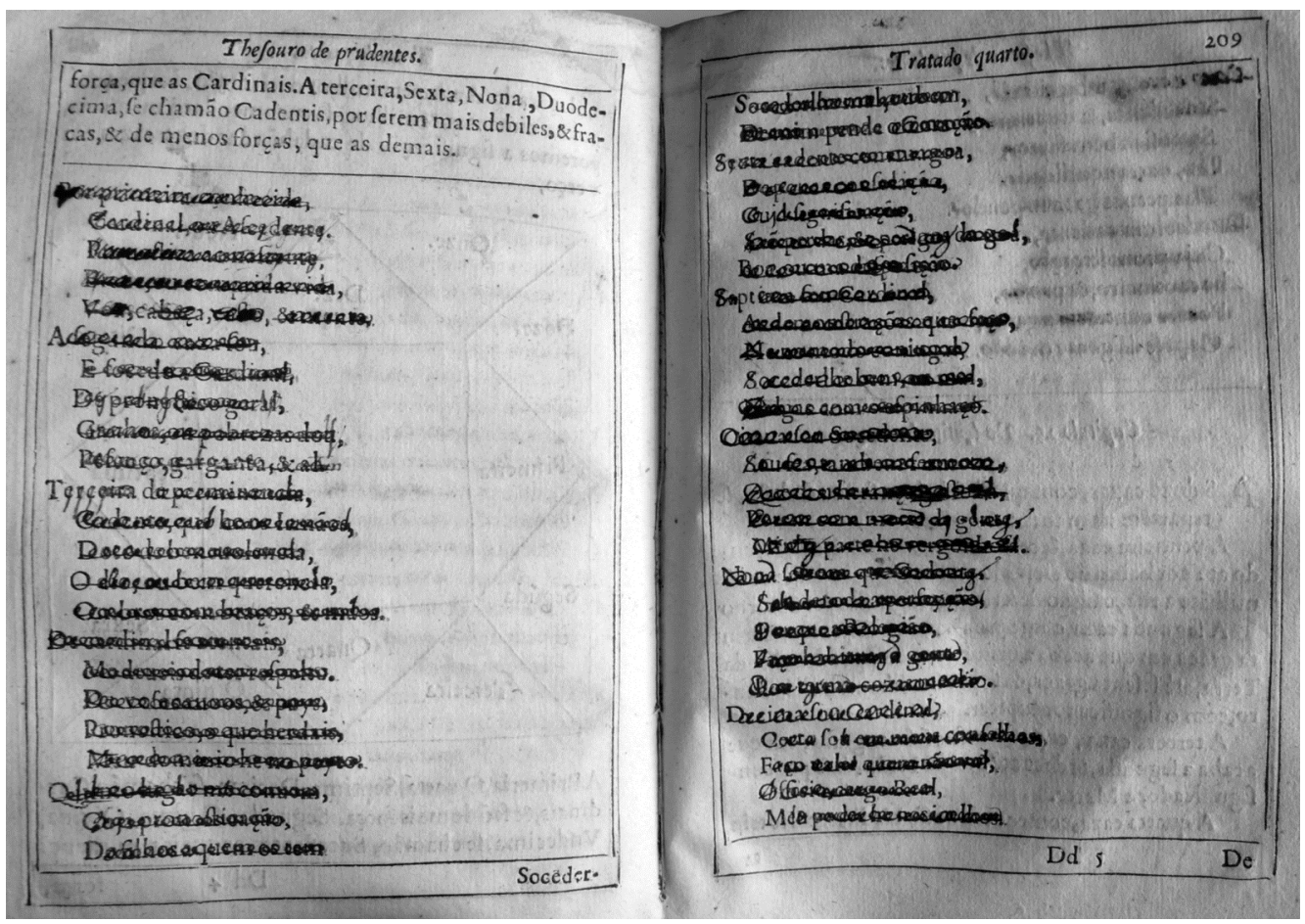

Figure .7 Parts of copies of Sequeira which have been erased. 
Hervé Baudry, «The Portuguese Medical Book Market (1601-1650) : a Good Business ? », in A Maturing Book Market? ed. Alexander Wilkinson (Leiden: Brill, Library of the Written Word, 2017, ch. 12, 225-240)

\begin{tabular}{|l|c|c|c|}
\hline $\begin{array}{c}\text { author, date of } \\
\text { printing }\end{array}$ & $\begin{array}{c}\text { original (O), } \\
\text { reprint (R) }\end{array}$ & $\begin{array}{c}\text { licensing } \\
\text { (1st and last) } \\
\text { year/month/day }\end{array}$ & $\begin{array}{c}\text { from licensing to } \\
\text { printing } \\
\text { (=: max. 12 } \\
\text { months) }\end{array}$ \\
\hline Cruz 1601 & $\mathrm{O}$ & $1601 / 03-05$ & $=$ \\
\hline Nunes 1601 & $\mathrm{O}$ & $1600 / 03-07$ & $=$ \\
\hline Lopes 1602 & $\mathrm{O}$ & $1601 / 12 / 14$ & $=$ \\
\hline Cardoso 1602 & $\mathrm{O}$ & $1696 / 05-1699 / 04$ & 3 \\
\hline Nunes 1603 & $\mathrm{O}$ & $1698 / 01-06$ & 5 \\
\hline Chamisso 1605 & $\mathrm{O}$ & $1602 / 10-1605 / 05$ & $2-3$ \\
\hline Cruz 1605 & $\mathrm{R}$ & $1604 / 11$ & $=$ \\
\hline Ramires 1608 & $\mathrm{O}$ & $1608 / 08$ & $=$ \\
\hline Sequeira 1612 & $\mathrm{O}$ & $1608 / 09-1611 / 12$ & 3 \\
\hline Cabreira 1613 & $\mathrm{R}$ & $1612 / 11-12$ & $=$ \\
\hline Cruz 1620 & $\mathrm{R}$ & $1619 / 08-1620 / 04$ & 1 \\
\hline Sabuco 1622 & $\mathrm{O}$ & $1616 / 10-1622 / 10$ & 5 \\
\hline Abreu 1623 & $\mathrm{O}$ & $1621-11 / 1622 / 01$ & $1-2$ \\
\hline Casmack 1623 & $\mathrm{O}$ & $1623 / 04-05$ & $=$ \\
\hline Cabreira 1624 & $\mathrm{R}$ & $1616 / 10-1624 / 10$ & 8 \\
\hline Fonseca 1626 & $\mathrm{O}$ & $1625 / 11-1626 / 03$ & $=$ \\
\hline Sequeira 1626 & $\mathrm{R}$ & $1625 / 09-1626 / 01$ & $=$ \\
\hline Cabreira 1635 & $\mathrm{R}$ & $1635 / 03-06$ & $=$ \\
\hline Castro 1636 & $\mathrm{O}$ & $1624 / 12-1635 / 08$ & 11 \\
\hline Arrais 1638 & $\mathrm{O}$ & $1638 / 01-02$ & $=$ \\
\hline Arrais 1642_1 & $\mathrm{O}$ & $1641 / 06-1642 / 02$ & $1-2$ \\
\hline Arrais 1642_2 & $\mathrm{O}$ & $1641 / 08-1642 / 07$ & 1 \\
\hline Bracamonte 1642 & $\mathrm{O}$ & $1642 / 06-10$ & $=$ \\
\hline Cruz 1649 & $\mathrm{R}$ & $1648 / 05-07$ & $=$ \\
\hline Arrais 1650 & $\mathrm{O}$ & $1649 / 08-12$ & $=$ \\
\hline
\end{tabular}

Figure 8 Licensing information.

Clearly, then, at least for the period under discussion, Inquisitorial bureaucracy did not seem to slow down medical book production, nor significantly hamper editorial activity. The concentration of the printing industry in Lisbon, in close proximity to the key decision makers, may even have aided the efficieny of the process.48 Licensing procedure (which generally took a matter of months) did not paralyze printing, but, beyond extending the production time, it could prohibit the circulation of texts and control its contents. 49

In terms of the importation of suspect works, any survey of copies held in Portuguese library collections today, or indeed of historical catalogues, leads us to the conclusion that heterodox ideas from Northern Europe, like paracelsian and iatrochemical treatises, began to circulate significantly only from the very late seventeenth century 
onwards.50 Before this point, any debate on these matters was very limited and references in Portuguese writings are scarce until the end of the seventeenth century.51 Due to the system of control, such an innovative and productive discipline as chemical medicine, was almost entirely absent from the Portuguese market.

An example of the depressed development of the Portuguese market is given, $a$ fortiori, by Garcia de Orta's Coloquios dos simples printed in Goa (India) in 1563, one of the rare places in the Portuguese 'Empire' - alongside Macau and Japan - where printing was authorized. Never printed in his native country before the nineteenth century, Orta's extraordinary success was originally due to a Latin translation by Charles de l'Écluse (Clusius) published four years later in Antwerp. Mostly it was translations (in Latin, Spanish, French and Italian), printed outside of Portugal, which circulated. Portuguese libraries own six copies of the original and at least thirty copies of the translated versions. When then was there no edition printed in Portugal, perhaps with some revisions? The reason is straightforward. Orta's daughter, Catarina, was condemned by the Goan Inquisition. Orta's own cadaver was exumed and burnt in 1580. No actual links exist between the processes and the book. As a heretic, that is a Protestant, Clusius, the translator of the Antwerp edition of 1567 was listed in the Spanish Index of 1632.

Except for a very few profitable texts, the Portuguese publishing world of the sixteenth and seventeenth centuries was not particularly interested in medicine. In fact, it represented just one per cent of total production. Many aspects of the circulation of medical works remain obscure, not least the extent to which such texts were imported from outwith the Peninsula. Some Portuguese authors certainly contributed, and in significant ways, to the advancement of medical understanding - not least Aleixo de Abreu on scurvy and Francisco Soares Feyo on yellow fever.52 However, in general, the picture is rather more bleak. Original editions of theoretical medicine tend to give way to practical medicine which were reprinted. This pattern can be linked directly to the decline of Renaissance humanism. New scientific breakthroughs, not least that represented by the new chemical school launched by Theophrastus Paracelsus (1493 or 1494-1541), remained almost unremarked upon in Portuguese medical literature until the very end of the seventeenth century. 
Hervé Baudry, « The Portuguese Medical Book Market (1601-1650) : a Good Business ? », in A Maturing

Book Market? ed. Alexander Wilkinson (Leiden: Brill, Library of the Written Word, 2017, ch. 12, 225-240)

\section{NOTES}

1 '[...] claro aumento da produção tipográfica ao longo do século', José J. Gonçalves, A Imprensa em Coimbra no século XVII (PhD thesis. Lisboa: Universidade Nova de Lisboa, 2010), p. 98.

2 Antonio J. Anselmo, Bibliografia das obras impressas em Portugal no século XVI (Lisboa: Biblioteca Nacional, 1926) lists 1312 items, while Iberian Books has recorded some 1,537. However, Iberian Books records has only one sixteenth-century medical book not contained in Anselmo. See also Alexander S. Wilkinson, 'Exploring the Print World of Early Modern Iberia', Bulletin of Spanish Studies, lxxxix, 4 (2012), pp. 491-506. For seventeenth-century numbers, see Iberian Books.

3 For a complete list, see Hervé Baudry, Bibliographia Medica Lusitana (Seventeenth-Century Portuguese Medical Book Bibliography), Nr. 1-37 (forthcoming). The 2 one-sheet cheap prints by Alexandrino (s.1., 1618) have not been taken into account. The total number of medical items for the sixteenth century (1556-1600) is 16 (of which 3 are reprints).

4222 medical items are known for the sixteenth century (totals calculated from the Bibliographia Medica Hispanica (Valencia: Universidad de Valencia-CSIC, 1987, vol. 2).

$5 \quad$ Elisabeth L. Furdell, Publishing and Medicine in Early-Modern England (Rochester: University of Rochester Press, 2002), p. 41; numbers based on Donald P. Wing's A Short-title catalogue of books printed in England, Scotland and Ireland, and of English books printed abroad 1475-1640 (London: The Bibliogrphical Society, 1976-1991); A Short-title catalogue of books printed in England, Scotland, Ireland, Wales, and British America, and of English books printed in other countries, 1641-1700 (New York: Modern Language Association of America, 1972-1998).

6 Noël Golvers, Portuguese books and their readers in the Jesuit mission of China: 17th-18th centuries (Lisboa: CCCM, 2011), p. 161 n. 228. In the eighteenth century, the French Jesuits were 'more concerned about medicine' than the Portuguese in China.

7 For Vesalius, there is one copy in Portugal of the 1543 edition (Joanina, University of Coimbra). A professor of anatomy at Coimbra, Alonso Rodrigues de Guevara published in 1559 a galenic treatise against Vesalius - In pluribus ex iis quibus Galenus impugnatur ab Andrea Vesalio Bruxelesi in constructione et usu partium corporis humani, defensio. Et nonnullorum quae in anatome deficere videbantur supplementum (Coimbra: apud João de Barreira, 1559, 8o) (ustc 345191). For the Reformação of the University of Coimbra of 1612, it was stated that one or two cadavers should be given every year by the city hospital for dissection, as in Salamanca, to explain Galen's treatise On the Use of the Parts. See Augusto da Silva Carvalho, 'A Medicina Portuguesa no século xvii', in Memórias da Academia das Ciências (Lisboa: Academia das Ciêcias, 1941), p. 340. See also Fernando T. da Fonseca, 'A Medicina', in História da Universidade de Coimbra (1537-1771) (Coimbra: Universidade de Coimbra-Fundação Calouste Gulbenkian, 1997), p. 841.

8 Juan de Valverde, Vivae imagines partium corporis humani aereis formis expressae (Antuerpiae: ex officina Christophori Plantini, 1566, 2o) (ustc 404504).

9 António da Cruz, Recopilação de cirugia (Lisboa: Per Jorge Rodriguez Impressor de livros, 1601, in-4o), 150r. The woodcut may come from a Spanish work (see 'Amistad' written between the legs).

10 The Antonio da Cruz treatise was a bestseller, going through 8 editions in the seventeenth century 5 before 1650). For Gaspar Cardoso Sequeira, see Thesouro de prudentes. Novamente tirado a luz (Coimbra: Nicolau Carvalho, 1612, 4o) (ustc 5013567), 71r; the engraving, copied with minor diferences, can be seen in the six subsequent reeditions (from 1626 to 1700).

11 Manuel de Azevedo, Correcção de abusos introduzidos contra o verdadeiro methodo da medicina. Em tres Tratados (Lisboa, Na Officina de Diogo Soares de Bulhoens, 1668, in-8o), p. 192.

12 In one case, at least - Antonio Pacheco Fabião, De hominis creatione (1635) -, the book was fully licensed and ready to print but remained in manuscript - see Diogo Barbosa Machado, Bibliotheca Lusitana (Lisboa: Francisco Luiz Ameno, 1759), vol. iv, p. 52.

13 In particular, the calculation was made on the basis of 'Tractatus [...]' = 1 item, which I concede tends to increase the possible number of books. See Baudry, Bibliographia Medica Lusitana, Part ii (forthcoming).

14 The first edition was Gonçalo Rodrigues de Cabreira, Compendio de muitos e varios Remedios de Cirugia, e outras cousas coriosas recopilados do Tesouro de Pobres e de outros graves Autores ([Lisboa] Por Antonio Alvarez, 1611, in-8o) (ustc 5000514).

15 Francisco Guilherme Casmack calls Chauliac a "very learned Frenchman" (Frances doutissimo) in 
Hervé Baudry, « The Portuguese Medical Book Market (1601-1650) : a Good Business ? », in A Maturing Book Market? ed. Alexander Wilkinson (Leiden: Brill, Library of the Written Word, 2017, ch. 12, 225-240)

his Relaçam Chyrurgica de hum cazo grave a que sucedeo mortificarse hum braço (Lisboa: por Geraldo da Vinha, 1623, in-4o) (ustc 5024199), p. 17v.

16 One third of Portuguese items were written by Cabreira and Cruz (10 editions).

17 Results obtained from located copies (one in-folio, 26 in-4o, 9 in-8o).

18 Andre Antonio de Castro, De febrium curatione libri tres (Villaviçosae: Apud Emmanuelem Carvalho, 1636) (ustc 5023950).

19 From 1601 to 1700, there are 78 known medical manuscripts in total, 54 in Latin, 24 in Portuguese and one in Spanish (it is a double copy of Saladino Ferro's Compendio de los buticarios (Valladolid: Arnao Guillen de Brocar, 1515, in-4o) (ustc 344340).

20 Ambrosio Nunes, or Nuñez, Tractado repartido en cinco partes principales, que declaran el mal que significa este nombre Peste (Conimbricæ: Diogo Gomes de Loureyro, 1601, in-4) (ustc 5008116); Tomus primus enarrationum in priores tres libros aphorismorum Hippochratis, cum Paraphrasi in Commentaria Galeni (Conimbricæ: Ex Officina Didacis Gomez Loureyro, 1603, in-4o) (ustc 5011562), was professor at Salamanca. In the sixteenth century, of 328 items (all fields) printed in this town, 121 were published by Portuguese authors - see Lorenzo Ruiz Fidalgo, 'Presencia de autores portugueses en la imprenta española en el siglo xvi', Leituras. Revista da biblioteca:O livro antigo em Portugal e Espanha séculos xvi-xviii, 9-10 (2001-2002), pp. 245-264. See also Ian Maclean on the 'very strong institutional connection' between both universities, in his Learning and the Market Place: Essays in the History of the Early Modern Book (Leiden: Brill, 2009), p. 386.

21 Antonio de Viana, Espejo de Cirurgia (Lisboa: s.n., 1631, in-4o) (ustc 5043438), with no copy known but a reprint in 1696; Andre Antonio de Castro, De febrium curatione libri très (Villaviçosæ: Apud Emmanuelem Carvalho, 1636, in-fol) (ustc 5023950).

22 Rita Marquilhas, A Faculdade das Letras. Leitura e escrita em Portugal no séc. xvii (Lisboa: INCM, 2000), pp. 185-186.

23 Jorge Peixoto, 'Aspectos económicos do livro em Portugal no século xvi', Gutenberg Jahrbuch (1965), pp. 142-149.

24 Two original texts: João Bravo Chamisso, De capitis vulneribus liber (Coimbra: per Didacum Gomes de Loureiro, 1610, in-4o) (ustc 5000561); Antonio de Viana, Espejo de Cirurgia (Lisboa: s.n.,1631, in-4o) (ustc 5043438) and three reprints: Oliva Sabuco, Nueva Filosofia (Braga: por Fructuose Loureço de Basto, 1612, in-16o); Gonçalo Cabreira, Compendio de muitos e varios remedios de cirugia (Lisboa: por Antonio Alvarez, 1614, in-8o) (ustc 5042147); João Valverde, Parecer do doutor Valverde, sobre a sangria do pe (Lisboa: por Geraldo da Vinha, 1627, in-4o) (ustc 5001255).

25 Cabreira's first edition of the Compendio de muitos e varios remedios de cirugia ([Lisboa:] por Antonio Alvarez [the father], 1611, in-8o) (ustc 5000514) is located in the Mindlin Collection (São Paulo, Brazil).

26 This analysis of medical book production rather goes against Thomas Earle's optimistic conclusions which oppose the suggestion of Portuguese backwardness, see his 'Portuguese Scholarship in Oxford in the Early Modern Period: The Case of Jerónimo Osório (Hieronymus Osorius)', Bulletin of Spanish Studies, lxxxi, 7-8 (2004), p. 1046.

27 On publishing in northern Portugal, production almost completely stops after 1650. See Marina de Matos, 'Impressores, editores e livreiros no Porto do século xv ao século xviii', Arquivo de bibliografia portuguesa, Nr. 61-62 (1970), pp. 105-120; Henrique Tavares Castro and Maria A.C. Maia, 'Produção impressa entre Douro e Minho nos sécs. xvii e xviii', O Colóquio sobre o livro antigo, Lisboa 1988, Actas (Lisboa: Biblioteca Nacional, 1992), pp. 187-205; and Lourenço de Sousa, 'Apontamentos biobibliográficos sobre os impressores e livreiros bracarenses nos séculos xvii e xviii', Museu. Revista de Arte, vol. 4 (1995), pp. 81-96.

28 César Manrique's investigations in this volume demonstrate that Lisbon was not on the export route from Flanders. From his investigations of the Beitang Library, China, Golvers (op. cit., pp. 58 and 73) points out the 'much manipulated' book of Sequeira, Thesouro de prudentes (Coimbra: Nicolau Carvalho, Jorge Rodrigues, 1612 or 1626, in-4o) (ustc 5013567) and three books by Portuguese physicians around the 1670s: Manuel de Azevedo, Correcção de abusos introduzidos contra o verdadeiro methodo da medicina (Lisboa: Na Officina de Diogo Soares de Bulhoens, 1668, in- $8^{\circ}$ ); António Teixeira, Epitome das noticias astrologicas para a medicina (Lisboa: Na Officina de Joam da Costa, 1670, in-4 ${ }^{\circ}$ ); Francisco Morato Roma, Luz da Medicina, pratica racional, e methodica (Lisboa: Antonio Crasbeeck de Mello, 1672, in-4o); see also Libraries of Western learning for China. Circulation of Western Books between Europe and China in the Jesuit Mission (ca. 1650-ca. 1750). 1 Logistics of book acquisition and circulation (Leuven: Leuven 
Hervé Baudry, «The Portuguese Medical Book Market (1601-1650) : a Good Business ? », in A Maturing Book Market? ed. Alexander Wilkinson (Leiden: Brill, Library of the Written Word, 2017, ch. 12, 225-240)

University Press, 2013).

29 Duarte Madeira Arrais, Novce Philosophice et medicince de qualitatibus occultis (Ulyssipone: Typis Emmanuelis Gomes de Carvalho, 1650, in-4o) (ustc 5015029), vol. 2, Disputatio 8, pp. 737-818. The cure of old age, and preservation of youth. By Roger Bacon, a Franciscan frier. Translated out of Latin; with annotations, and an account of his life and writings. By Richard Browne, M.L. Coll. Med. Lond. Also a physical account of the tree of life, by Edw. Madeira Arrais. Translated likewise out of Latin by the same hand (London: printed for Tho. Flesher at the Angel and Crown, and Edward Evets at the Green Dragon, in St Pauls Church-yard, 1683, in-8o), 'A Piece useful for Divines as well as Physicians' (title page of the treatise); in the letter to the reader, Browne alludes to the daughter of João IV, Catarina de Bragança, who married Charles II in 1662.

30 Ambrosio Nunes, Tractado repartido en cinco partes principales, que declaran el mal que significa este nombre Peste (Conimbricæ: Diogo Gomes de Loureyro, 1601, in-4o) (ustc 5008116); Tomus primus enarrationum in priores tres libros aphorismorum Hippochratis, cum Paraphrasi in Commentaria Galeni (Conimbricæ: Ex Officina Didacis Gomez Loureyro, 1603, in-4o) (ustc 5011562), with, respectively, 36 and 10 copies located. Ferdinandus Rodericus Cardoso, Tractatus de sex rebus non naturalibus nunc primum in lucem editus (Ulyssipone: Ex officina Georgii Rodriguez, 1602, in-4o) (ustc 5006643). His work was reedited in Francfort (typis Pauli Jacobi, 1620, in-8o) (ustc 2005701) and he published another treatise in Italy, Methodus medendi (Venetiis: apud Vincentium Somaschum, 1618, in-4o) (ustc 4027815).

31 Ambrosio Nunes, Tractado repartido en cinco partes principales, que declaran el mal que significa este nombre Peste (Conimbricæ: Diogo Gomes de Loureyro, 1601, in-4o) (ustc 5008116); António da Cruz, Recopilação de cirugia, (Lisboa: Por Antonio Alvarez, A custa de Hieronymo Lopez mercador de livros, 1605, in-8o) (ustc 5034959).

32 Compendio de muitos e varios remedios (Lisboa: por Antonio Alvarez, 1635, in-8o) (ustc 5024908). The copy at the Biblioteca Pública de Braga (Res. 151 (2) A) is bound with three Portuguese books of seventeenth-century religious poetry.

33 See Jean-Frédéric Schaub, Portugal na Monarquia Hispânica (1580-1640) (Lisboa: Livros Horizonte, 2001).

34 Duarte Madeira Arrais, Methodo de conhecer e curar o morbo gallico (Lisboa: Na officina de Lourenço de Anveres, 1642, in-4o) (ustc 5023320), 8v. Thanks to João IV, the Restorer, 'Portugal recovered health' on 1 December 1640.

35 Ana Paula Megiani, 'Imprimir, regular, negociar: elementos para o estudo da relação entre Coroa, Santo Ofício e Impressores no Mundo Português (1500-1640)', Anais de História de Além-mar, 7 (2006), p. 250 .

36 Megiani, 'Imprimir, regular', pp. 236-237.

37 See Ian Maclean, op. cit., Chapter 13: "Lusitani periti': Portuguese medical authors, national identity and bibliography in the late Renaissance'.

3870 per cent of the 55 surviving copies in Portuguese libraries of the widely circulated Amato Lusitano's Centuriae Curationum (published 1551-1620) have been expurgated; 43 per cent for the 30 copies of Zacuto Lusitano's (1629-1667) works.

39 Giuseppe Marcocci and José P. Paiva, História da Inquisição Portuguesa (Lisboa: A Esfera dos Livros, 2013), Chapter vi.

40 Manuela D. Domingos, 'Visitas do Santo Ofício às naus estrangeiras. Regimento e quotidianos', Revista da Biblioteca Nacional (1993), p. 155. Large evidence of expurgation leads me to conclude the contrary of this other assertion that 'the inquisidores almost did not care at all about scientific books', Henrique Leitão and Lígia Martins, O Livro Científico dos Séculos xv e xvi. Ciências Fisico-Matemáticas na Biblioteca Nacional (Lisboa: Biblioteca Nacional, 2004), p. 50.

41 Denouncement by individuals was fundamental - see the table in José Pardo Tomás, Ciencia y Censura. La Inquisición Española y los libros científicos en los siglos xvi y xvii (Madrid: csic, 1991), p. 26.

42 Gonçalo Cabreira, Compendio de muitos e varios remedios de cirugia ([Lisboa:] Por Antonio Alvarez, 1611, in-8o) (ustc 5000514); Gaspar Cardoso de Sequeira, Thesouro de prudentes (Coimbra: Nicolau Carvalho, Jorge Rodrigues, 1612, in-4o) (ustc 5013567). Nueva Filosofia (Braga: Fructuoso Lourenço de Basto, 1622, in-8o) (ustc 5004318). João F. Arouca, Bibliografia das obras impressas em Portugal no século xvii (Lisboa: Biblioteca Nacional, 2001-2011, 4 vol.), vol. 4, p. 28, nr. 34, knows one emission, with armorial bearings on the front-page ('Escudo das armas do Barão de Alvito') and the tax printed (' 140 reis') and dated (5.10.1622); another emission presents two women sitting on an armillary sphere, the tax remains blank, which leads us to conclude that this was the first emission. On the question 
Hervé Baudry, « The Portuguese Medical Book Market (1601-1650) : a Good Business ? », in A Maturing Book Market? ed. Alexander Wilkinson (Leiden: Brill, Library of the Written Word, 2017, ch. 12, 225-240)

of the book's authorship, Oliva, and not her father, Miguel Sabuco, see Esther Maria Villegas de la Torre, Women and the Republic of Letters in the Luso-Hispanic World, 1447-1700 (PhD, University of Nottingham, 2011, pp. 131-139).

43 Index Auctorum damnatae memoriae. Tum etiam librorum, qui vel simpliciter, vel ad expurgationem usque prohibentur, vel denique expurgati permittuntur (Ulyssiponae: ex off. Petri Craesbeck, 1624, in-fol.) (ustc 5015927).

$44 \quad$ Novus index librorum prohibitorum et expurgatorum (Hispali: ex typogr. F. de Lyra, 1632, infol.) (ustc 5007741), Novissimus librorum prohibitorum ex expurgandorum index (Madriti: Ex Typographae Didaci Diaz, 1640, in-fol.) (ustc 5006733).

45 The passage to expurgate (Lisbon Index, 595) is a poem of astrological content.

46 Four of the five copies existing in Portuguese libraries were expurgated.

47 The licensing process had two phases: October 1616-January 1617, October 1624.

48 Another factor to be taken into account on this issue is the comparatively small role played by the university, linked with the major role of practical vernacular medical books. This point is inspired by the study on the diffusion of learned medicine in Maclean (op. cit., Chap. 4, in part. pp. 63-65).

49 Taxing puts an end to the licensing process but, probably, some books circulated before being taxed. Some items of the second half of the century show that taxing remains blank. A last remark: taxes are commonly used to evaluate the price of the paper. In one case, at least, it may reflect a policy on books: if we calculate in terms of sheets, Cabreira's Compendio (Lisboa : por Antonio Alvarez, 1635, in-80) (ustc 5024908 ) is about 3 times more heavily taxed than Arrais, Apologia em que se defendem humas sangrias de pes (Lisboa: Antonio Alvares, 1638, in-4o) (ustc 5039447) - both taxed 500 reis according to 11 and 28 sheets respectively.

50 In João Curvo Semedo’s Polyanthea Medicinal. Noticias Galenicas e Chymicas (Lisboa: Miguel Deslandes, 1697, in-fol.) the censor Manuel Soares Brandão argues in favour of the conciliation of Hippocratic and chemical medicine, but does not mention Paracelsus.

51 Hervé Baudry, 'The question of the early reception of Paracelsus and Paracelsianism in Portuguese medicine' (paper presented at the conference 'Portuguese Physicians in the Early Modern Period Geographical Expansion and Medical Prudence', The Warburg Institute, University of London, 18-19 February 2011; to be published).

52 On scurvy, see Tratado de las siete enfermedades (1623) (ustc 5016890) and Rosa, Trattado unico da Constituiçam pestilencial de Pernambuco (1694). On yellow fever, see Recopilaçam de cirugia (1649) (ustc 5004987). 